\title{
Effects on Soil P Content, P Sorption and Risk of Eutrophication of Waterbodies of Outdoor Pig Production
}

\section{Areas}

Carmo Horta ${ }^{1,2 *}$ and Natália Roque ${ }^{1,2,3}$

1 Polytechnic Institute of Castelo Branco, School of Agriculture, Quinta da Sra. de Mércules, 6001-909 Castelo Branco, Portugal;

2 CERNAS-IPCB Research Centre for Natural Resources, Environment and Society, Polytechnic Institute of Castelo Branco, 6001-909 Castelo Branco, Portugal;

3 Quality of Life in the Rural World - Research Unit (QRural)/Polytechnique Institute of Castelo Branco, 6001909 Castelo Branco, Portugal.

* Correspondence: carmoh@ipcb.pt; Phone: +351272339900; Fax: +351272339901

\begin{abstract}
The Mediterranean region offers good weather conditions for outdoor pig production (OPP), which is considered more environmentally friendly than intensive indoor production. However, the continuous input of food and pigs' excreta increases the soil organic matter (SOM) and phosphorus $(\mathrm{P})$, increasing the risk of waterbodies eutrophication. This work aimed at evaluating in OPP areas soil $\mathrm{P}$ dynamics and the role of SOM on $\mathrm{P}$ sorption and $\mathrm{P}$ release. The experiment was done for two years, at an area of 2.8 ha with an animal charge of 9 adults ha-1. Georeferenced soil samples were taken at $0.20 \mathrm{~m}$ depth, and a soil P sorption experiment was carried out. At the end of the experiment, for the background value, the levels of SOM increased between 85-376\%, and Olsen $P$ values ranged between - $82-884 \%$. SOM levels above $2 \%$ caused a decrease in the binding energy of $\mathrm{P}$ sorption according to the linear model $b=-$ 15.541SOM+115.20 $(p<0.01)$ as well as a decrease of the soil P sorption capacity $Q \max =-$ 41.272SOM+298.37 $(p<0.01)$. To avoid the accumulation of SOM and P preventing hotspots for waterbodies eutrophication, an adequate animal charge together with soil cultivation for pig grazing can be a cost-effective practice.
\end{abstract}

Keywords: eutrophication; phosphorus sorption; soil Olsen P; soil organic matter.

\section{Introduction}

High phosphorus levels $(\mathrm{P})$ in the soil causes potential risks for the eutrophication of waterbodies throughout non-point source pollution. In the agricultural soils, the increase in soil $P$ could be achieved by the uneven input of $P$ from mineral fertilizers or livestock manures in excess regarding the crop needs and the soil capacity to sorb $\mathrm{P}[1,2]$. Overfertilized agricultural soils are currently assumed as the primary source of $\mathrm{P}$ for the eutrophication of waterbodies through soil erosion and losses of $\mathrm{P}$ to drainage or runoff waters [3]. However, in outdoor livestock production areas, the daily addition to soil of $\mathrm{P}$ contained in food and animal excreta also caused an increase not only in soil $\mathrm{P}$ but also in SOM [4-8]. Since soils have a limited capacity to sorb $P$, this surplus of $P$ causes an increase in soil solution with a high potential to be transferred to drainage or runoff waters, increasing the risk of eutrophication of waterbodies and decreasing the drinking water quality [9]. Soil P sorption could be defined as the transfer from soil solution to the solid soil phase of the orthophosphate anion, irrespective of which primary process occurs, be it adsorption or precipitation. This process involves electrostatic and ligand exchange adsorption processes in addition to various types of precipitation reactions [10]. In acid soils, the main P-sorbing surfaces are $\mathrm{Al}$ and Fe oxides, hydroxides, and oxyhydroxides 
$[10,11]$ and organic complexes of $\mathrm{Al}$ and $\mathrm{Fe}[12,13]$. So, the soil properties of the solid soil phase are determinant factors for the soil $\mathrm{P}$ sorption capacity. Several researchers reported the effect of the SOM in preventing P sorption in agricultural soils and consequently the increase in the risk of soil P losses. Gérard [14] and Guppy et al. [15] summarized the conclusions of several works and showed some contradictory results about the role of SOM on soil P sorption. Some works referred that the addition of organic matter causes a significant decrease of soil $\mathrm{P}$ sorption attributed to a competitive effect to the same sorption sites between the organic acids produced during the mineralization of SOM and the orthophosphate anions [16-18]. In other works, increasing SOM could increase the formation of metal bridges creating new P sorption sites [19], or the mineralization of SOM could release inorganic $P$ to soil solution $[20,21]$. The composition of the $\mathrm{OM}$ and the degree of its humification seems to be the main factors affecting the effect of SOM on the soil P sorption capacity. Mediterranean region offers good weather conditions for outdoor pig production (OPP), which is a way of having animal production with low capital cost to establish [22-24]. It is also considered as a more environmentally and animal-friendly production compared with intensive indoor production. These are the main reasons for the increasing interest in pig production [25]. The effects of OPP in increasing SOM and nutrients, namely $\mathrm{P}$, are well reported [26-30]. However, the role of the increasing SOM on P sorption and soil P dynamics in OPP areas are not so well studied.

In this work, we tested the hypothesis that OPP can behave as hotspots of high risk for non-point source $\mathrm{P}$ pollution at the catchment scale because of their potential to maintain high levels of labile soil $\mathrm{P}$ not only through soil $\mathrm{P}$ accumulation but also through the role of SOM in decreasing soil P sorption capacity. So, we evaluated at an experimental OPP (i) the spatial variation of soil P forms (inorganic, organic and labile P), (ii) the spatial variation of soil organic matter, and (iii) the initial value and the evolution during the experiment of the P sorption capacity of the soil. This work was conducted for 25 months from the beginning of the OPP.

\section{Materials and Methods}

This experiment was carried out at an outdoor pig production area on a farm belonging to the School of Agriculture of the Polytechnic Institute of Castelo Branco, Portugal. (39.822054 ${ }^{\circ} \mathrm{N},-7.448026^{\circ} \mathrm{W}$ Decimal Degrees, WGS 84 coordinates). The study period was from January 2005 to February 2007.

\subsection{Characterization of the experimental unit of outdoor pig production}

OPP consisted of an area of 2.8 ha divided into six paddocks (Fig. 1a). This OPP evaluated the behaviour of two local breeds, Alentejana and Bísara. So, in paddock 1 (Pk1, Figure 1a), there were two males, one of each breed, paddock 2 had the pregnant/lactating Alentejana females, paddock 3 had pregnant/lactating Bísara females, in paddock 4 there were the Bísara females, and in paddock 5 there were the Alentejana females. Paddock 6 had the weaned piglets. The experimental area had on average a charge of one animal adult per $1.136 \mathrm{~m}^{2}$. The OPP had 18 adult females, 9 of each breed, which had two parturitions per sow per year with an average of five piglets per parturition. Piglets were sold after 60 days of birth. Average food intake per animal and day was between 2.5 and $3.5 \mathrm{~kg}$ of commercial concentrates with a P concentration in dry matter of $0.4 \%$, but for pregnant/lactating females, the concentrate had $0.7 \%$ of $\mathrm{P}$. This area was neither cultivated nor fertilized so, $\mathrm{P}$ and organic matter inputs were due only to the feed and pig excreta. 


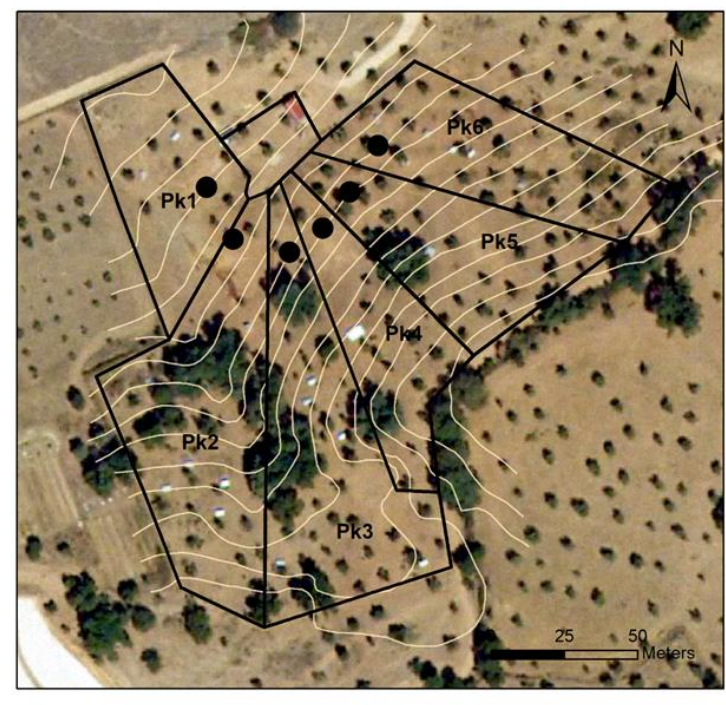

\section{a)}

\section{Legend}
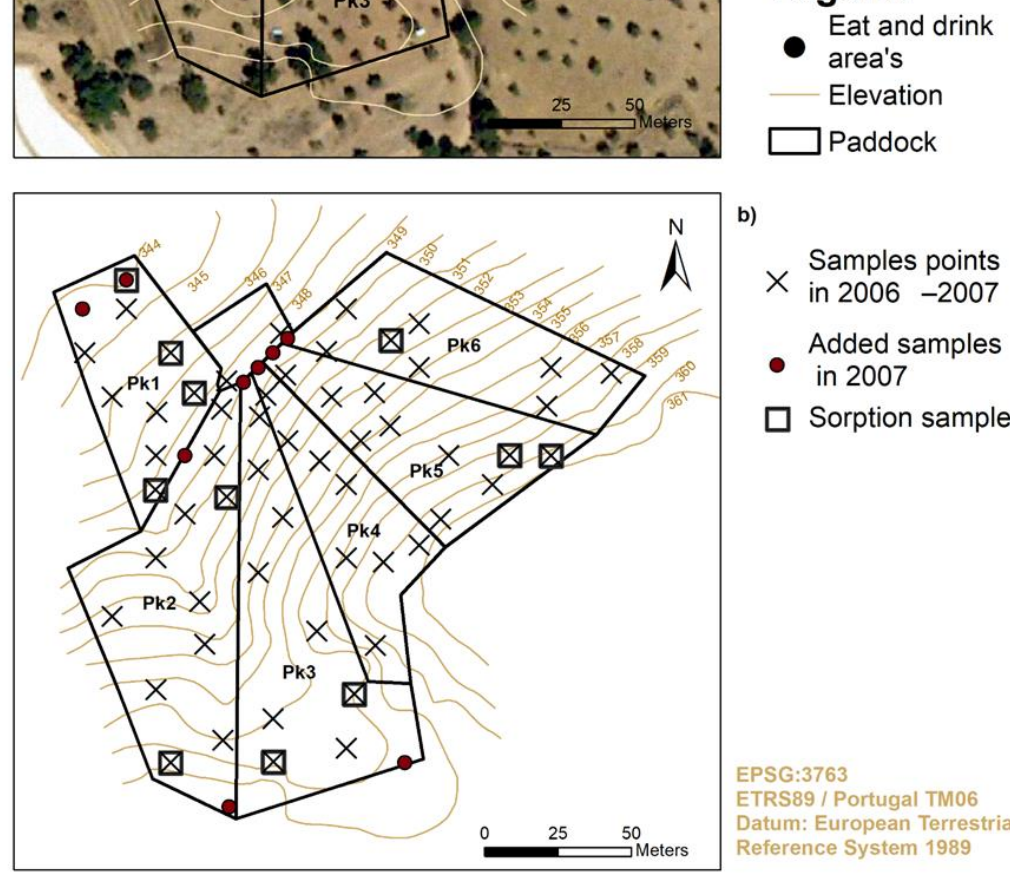

b)

$$
\begin{aligned}
& \text { Samples points } \\
& \text { in } 2006-2007 \\
& \text { Added samples } \\
& \text { in } 2007 \\
& \square \text { Sorption samples }
\end{aligned}
$$

Figure 1. Paddock (Pk) Location: a) Outdoor pig production area with the paddocks, feeders and wells points. b) Soil sample points and elevation of the area.

The feed and water points are fixed (Figure 1a) near the paddocks door and located in lower elevation spots inside each paddock.

\subsection{Characterization of climate, topographic location and soil properties}

The region has a Mediterranean climate, with an average (1986-2015) temperature of $15.0^{\circ} \mathrm{C}$ (during this period, the average maximum temperature was 21.5 and the average of the minimum temperatures was $9.4^{\circ} \mathrm{C}$ ) and $735 \mathrm{~mm}$ of annual rainfall. Total rainfall in the experiment period was: $812.1 \mathrm{~mm}(01 / \mathrm{Jan} 2005$ to $12 / \mathrm{Jun} / 2006)$ and $702.1 \mathrm{~mm}$ (13/Jun/2006 to 01/Feb/2007). The dry season is from June to September, with a rainfall of $112.4 \mathrm{~mm}[31]$.

There are some Quercus (Quercus suber L.) trees in Paddocks 2 and 3 and Olive (Olea europea $\mathrm{L}$ ) trees in all the area.

Soil properties were evaluated by sampling soil as follows: 56 positioned randomized soil samples were taken in all the area ( $2.8 \mathrm{ha}$ ) from a network of $5 \times 5 \mathrm{~m}$ at the beginning of the experiment and on June 12, 2006. On February 1, 2007, another soil sampling was done in the same positioned soil samples, and another seven samples were collected in sites with visual variations of SOM (Figure 1b). This procedure allowed to identify the 
variation (increase/accumulation or decrease/loss) on soil properties mainly in the SOM and soil P forms during the experiment. The depth of soil sampling was always $0.20 \mathrm{~m}$. The soil samples taken in June 2006 and February 2007 were analyzed for organic matter $(\mathrm{OM})$, inorganic $\mathrm{P}(\mathrm{Pi})$, organic $\mathrm{P}(\mathrm{Po})$ and labile $\mathrm{P}$ quantified by the Olsen procedure (Olsen P).

Background soil properties were evaluated before the beginning of the experiment in January 2005. Variability between the 56 soil samples was very low so, we took the average values to characterize the background soil properties (Table 1). The soil of the experimental area is a Dystric Cambisol [32], sandy loam (clay 11.4\%, silt $10.3 \%$ and sand $78.3 \%$ ), acid, poor in organic matter and with a low level of nutrients.

Table 1. Background soil properties (January 2005, $n=56$, average \pm SD)

\begin{tabular}{cccc}
\hline Soil properties & Unites & Average & SD \\
\hline $\mathrm{pH}$ & - & 5.1 & $( \pm 0.1)$ \\
\hline $\mathrm{EC}$ & $\mathrm{dS} \mathrm{m}^{-1}$ & 0.047 & $( \pm 0.015)$ \\
\hline $\mathrm{OM}$ & $\%$ & 1.4 & $( \pm 0.12)$ \\
\hline $\mathrm{Ca}^{2+}$ & $\mathrm{cmol}_{(+)} \mathrm{kg}^{-1}$ & 0.35 & $( \pm 0.06)$ \\
$\mathrm{Mg}^{2+}$ & & 0.09 & $( \pm 0.02)$ \\
$\mathrm{Na}^{2+}$ & & 0.01 & $( \pm 0.00)$ \\
$\mathrm{K}^{+}$ & & 0.05 & $( \pm 0.01)$ \\
\hline $\mathrm{Olsen}-\mathrm{P}$ & $\mathrm{mg} \mathrm{kg}^{-1}$ & 5 & $( \pm 1)$ \\
$\mathrm{Pi}$ & & 64 & $( \pm 7)$ \\
$\mathrm{Po}$ & & 140 & $( \pm 11)$ \\
\hline
\end{tabular}

\subsubsection{Sorption experiments}

Sorption experiments were done on eleven soil samples of selected points sampled on June 2006 and on February 2007 (Figure 1b), and a composite soil sample was taken at the beginning of the experiment (background value). These soil samples had significant differences in the OM content ranged between 1.2 and 4.6\%. The method of Fox and Kamprath ([33] 1970) was used to construct the P sorption curves (i.e. Q/I) and the supporting electrolyte used was $0.002 \mathrm{M} \mathrm{CaCl}_{2}$. The $\mathrm{P}$ rates $\left(\mu \mathrm{g} \mathrm{P} \mathrm{g}{ }^{-1}\right.$ soil) applied to the soil samples were: $0,30,50,80,100,120,150$ and 180 . Sorption data were fitted to the Langmuir isotherm adsorption equation:

$$
Q s+Q n a t=\frac{K Q \max C}{1+K C}
$$

where $\mathrm{K}$ is a constant typical of each soil, and Qmax is the maximum amount of $\mathrm{P}$ that soil can sorbed and C is P concentration in soil solution in equilibrium with sorbed P.

The amount of $\mathrm{P}$ sorbed by the soil is the combination of that $\mathrm{P}$ sorbed in the sorption experiment (Qs), and that sorbed previously by the soil [i.e. 'native sorbed $\mathrm{P}^{\prime}(\mathrm{Q}$ at)]. We used Olsen P to estimate Qnat [34]:

$$
\text { Qnat }=12.1\left(\frac{\text { Olsen } P}{\mathrm{pH}}\right)
$$

Sorption data were also fitted to the Temkin equation:

$$
Q s+Q n a t=\mathrm{a}+\mathrm{bln} C
$$

Qs, Qnat and C have the same meaning as in the Langmuir isotherm, and the Temkin isotherm's b parameter (slope) is related to the affinity to phosphate to the mineral 
sorption sites. A decrease in the $\mathrm{b}$ value indicates permanent blocking of sorption sites [35].

\subsection{Soil analysis}

Soil samples were air-dried and sieved $(<2 \mathrm{~mm})$. The $\mathrm{pH}$ was measured using a $\mathrm{pH}$ electrode by taking $10.0 \mathrm{~g}$ of dried and sieved soil and $25 \mathrm{~mL}$ of distilled water (1:2.5 soil: solution ratio) which were in contact for $1 \mathrm{~h}$. The EC was measured with a conductivimeter at a suspension of soil: water ratio of 1:2 after 60 min shaking. According to the procedure described in Walkley and Black, the organic matter was analyzed using a potentiometric titration method [36]. The soil texture was evaluated by the particle size analysis using the pipet method [37]. The contents of $\mathrm{Ca}, \mathrm{Mg}, \mathrm{K}$ and $\mathrm{Na}$ were measured by atomic absorption spectrometer after extraction with a molar solution of $\mathrm{CH}_{3} \mathrm{COONH}_{4}$ buffered at $\mathrm{pH}$ 7.0. The procedure of Olsen et al. [38] was used to quantify the labile soil P (Olsen P), i.e. not only the soil $\mathrm{P}$ available to the crops but also the transfer from soil to runoff waters [39]. The inorganic and the organic soil $\mathrm{P}$ forms were evaluated by the procedure of Olsen and Sommers [40]. The content of P in all the extracts was quantified by the method of Murphy and Riley [41].

\subsubsection{Data analysis}

Regression analysis was used to fit the sorption data to sorption models (Eq. 1 and 3). Regression and correlation analysis were used to evaluate (i) the effect of SOM on P sorption assessed by the isotherm sorption constants (Langmuir-Qmax and Temkin-b) and (ii) the relationship between soil P forms. The changes $(\Delta, \%)$ in SOM, Olsen P, Pi and Po during the experiment (January 2005 to February 2007) were evaluated by the following equation:

$$
\Delta(\%)=100 x \frac{\text { (soil value }- \text { background soil value) }}{\text { background soil value }}
$$

The maps with the spatial distribution of the changes in 2006 and $2007(\Delta, \%$; Equation 4) of SOM, Olsen P, Pi and Po were done using the georeferenced data of the soil samples. Regression and correlation analysis was done with IBM SPSS statistics 26 software (www.spss.com) and the maps with the spatial distribution of SOM and soil P forms with ArcGIS 10.8.

\section{Results}

The effect of OPP on the spatial distribution of SOM, P forms (Olsen P, Pi, Po) and soil P sorption capacity is given below.

\subsection{Spatial distribution of SOM and soil P forms}

The positioned soil samples allowed the evaluation of the changes on SOM and soil P forms throughout the experiment, from January 2005 (the beginning of the OPP) till June 2006 (after 17 months) and till February 2007, in total after 25 months (Figures 2 and 3). At the end of the two-years experiment, an overall SOM accumulation above the background value $(1.4 \%)$ at the OPP area can be observed. In 2006 the SOM content ranged between 0.1 and $3.8 \%$, with a variation about the background SOM value of -93 to $174 \%$. However, in 2007 a net accumulation in the whole area, with SOM ranged from 2.6 to $6.6 \%$ and a variation from 85 to $376 \%$ was verified.

In both years, the soil Olsen $\mathrm{P}$ showed spots with $\mathrm{P}$ losses and $\mathrm{P}$ accumulation concerning the background value (Olsen $\mathrm{P}=5 \mathrm{mg} \mathrm{kg}^{-1}$ ). Thus, in 2006 Olsen $\mathrm{P}$ ranged between 1 to $48 \mathrm{mg} \mathrm{kg}^{-1}$ with a variation about the background value of -80 to $860 \%$. In 2007 the Olsen P ranged from 1 to $49 \mathrm{mg} \mathrm{kg-1}$ with a variation between -82 to $884 \%$.

Soil Pi ranged from 38 to $351 \mathrm{mg} \mathrm{kg}^{-1}$ in samples taken in 2006 with a variation from -40 to $449 \%$ in relation to the background value $\left(64 \mathrm{mg} \mathrm{kg}^{-1}\right)$. In 2007 the Pi variation was from -40 to $664 \%$, with a soil content ranged between 39 to $489 \mathrm{mg} \mathrm{kg}-1$. Concerning soil 
Po, the variation was from -22 to $133 \%$ and from -25 to $190 \%$ in 2006 and 2007, respectively (background value of $140 \mathrm{mg} \mathrm{kg}^{-1}$ ). In 2006 the content of soil Po was between 107 and 326 $\mathrm{mg} \mathrm{kg}^{-1}$ and in 2007 from 104 to $406 \mathrm{mg} \mathrm{kg}^{-1}$.

According to Fernández et al. [42], pigs can excrete $1.2 \mathrm{~kg}$ P for each $100 \mathrm{~kg}$ of live weight, with the growing pigs contribute $59 \%$ to P excretion, sows with $26 \%$ and weans with $15 \%$. Considering the live weight of the pigs in our OPP (data not shown) in paddock 6, for example, the total P input m-2 was around $190 \mathrm{~kg} P$ (from 2005 to 2007).

Labile soil $\mathrm{P}$ (Olsen $\mathrm{P}$ ) was a small fraction of $\mathrm{Pi}$ on average $11 \%$, as seen by the Equation 5:

$$
\text { Olsen P }\left(\mathrm{mg} \mathrm{kg}^{-1}\right)=0.108 \mathrm{Pi}-2.229 \quad \mathrm{R}^{2}=0.63(p<0.001) \text {. }
$$

Olsen P was not correlate with soil Po $(p>0.05)$.

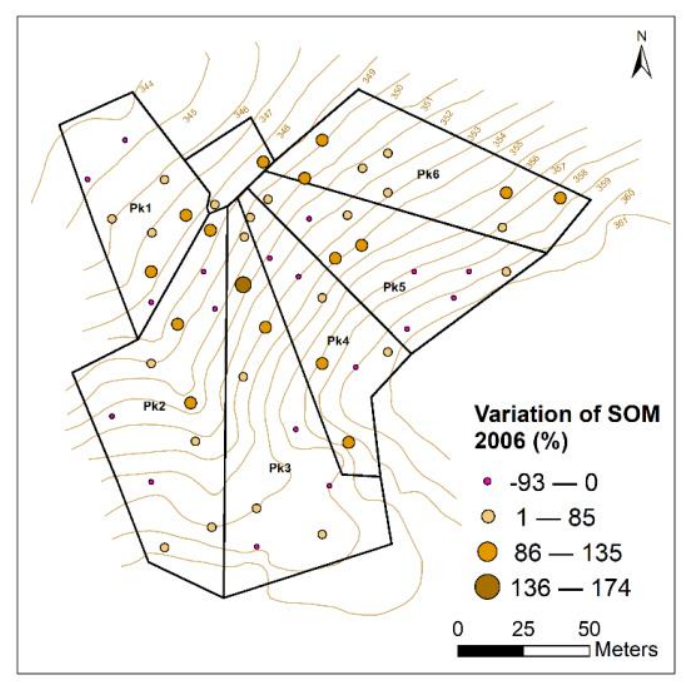

(a)

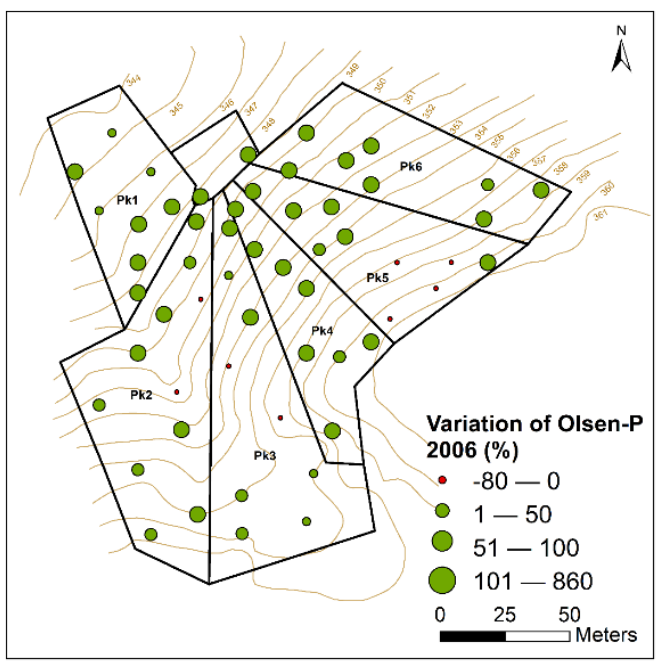

(c)

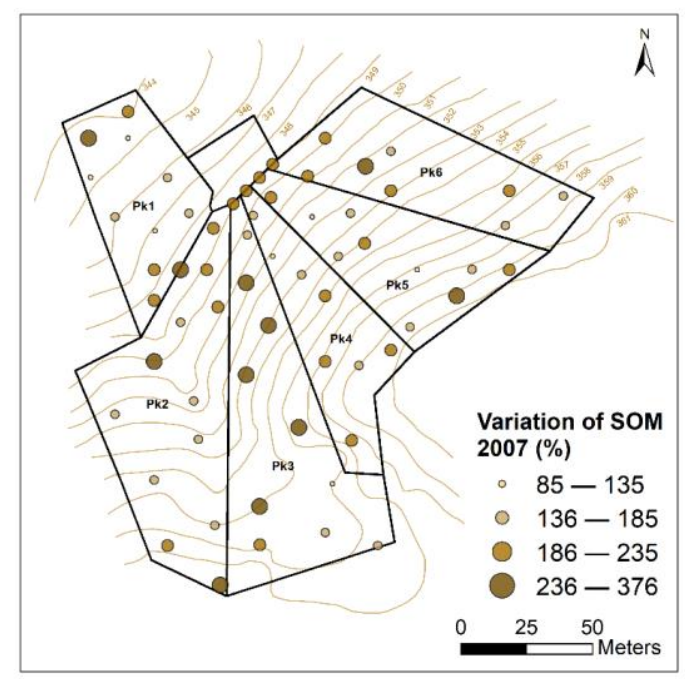

(b)

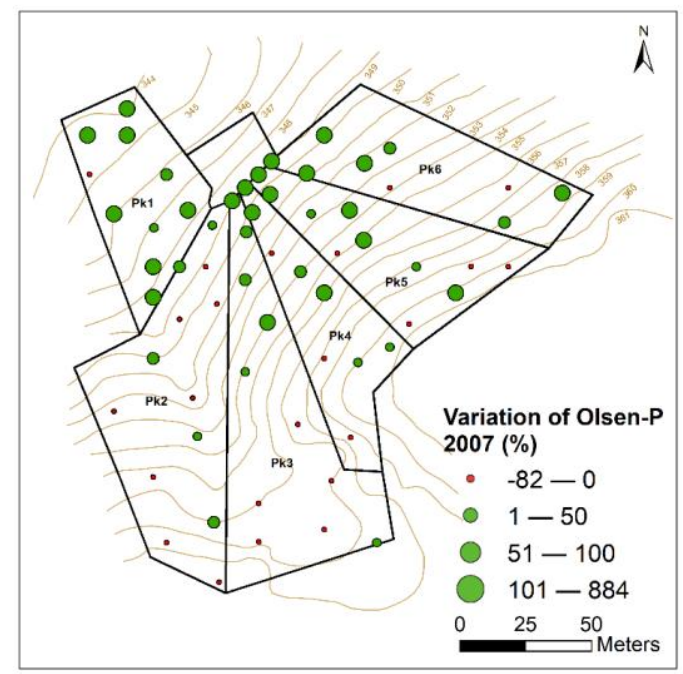

(d)

Figure 2. Spatial distribution of the variation of SOM and Olsen-P in relation to the initial value (\%); (a) and (c) June 2006, (b) and (d) February 2007. 


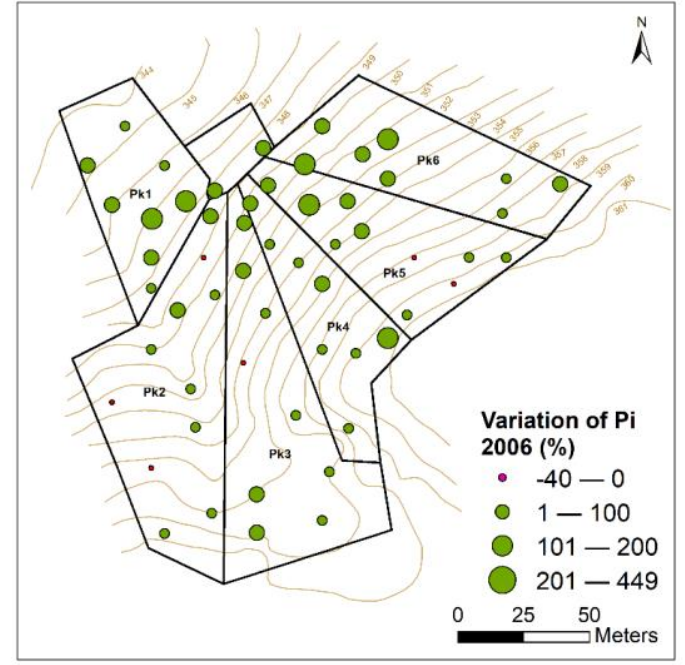

(a)

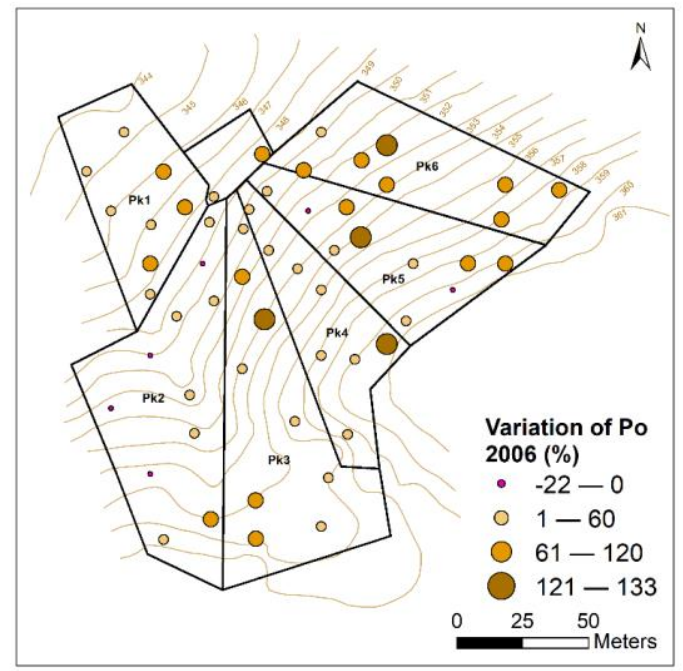

(c)

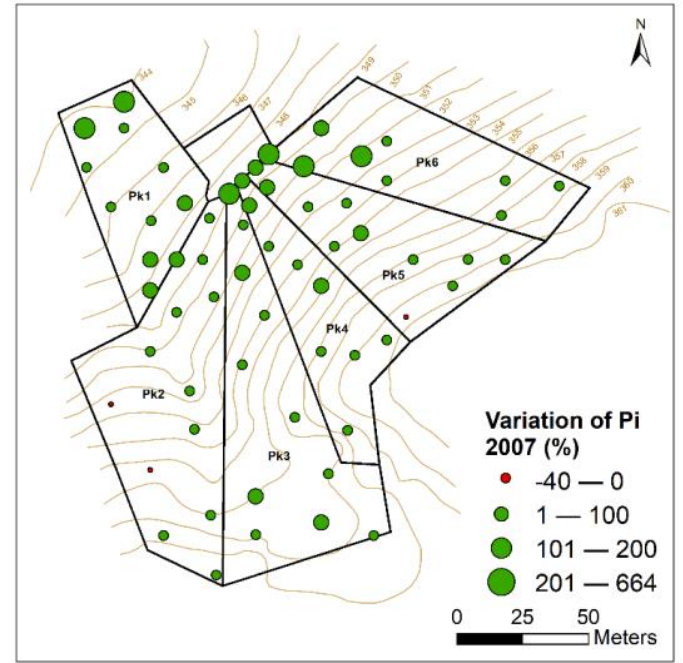

(b)

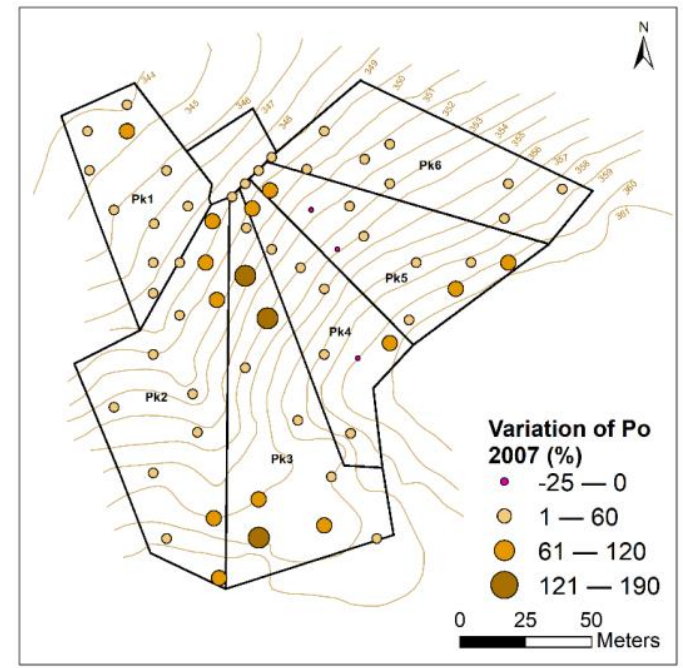

(d)

Figure 3. Spatial distribution of the variation of Pi and Po about the initial value (mg kg-1; (a) and (c) June 2006, (b) and (d) February 2007.

\subsection{Soil P sorption}

The native soil showed a low value of Qmax (142 $\left.\mathrm{mg} \mathrm{kg}^{-1}\right)$, following the values observed in soils of the Temperate zone. These soils are moderately weathered, having low to medium levels of Fe and Al hydroxides. Daly et al. [43] referred to values of Qmax between $263-625 \mathrm{mg} \mathrm{kg}^{-1}$ for a set of Irish soils with contrasting chemical properties. The Portuguese soils with similar properties [34] estimate that Fe and Al hydroxides of low crystallinity together with organic complexes of Fe and $\mathrm{Al}$ are the main P sorbing surfaces. The binding energy of phosphate to the solid soil phase (the $b$ value of the Temkin isotherm) was $71.9 \mathrm{~L} \mathrm{~kg}^{-1}$.

The sorption experiment showed that the soil $\mathrm{P}$ sorption capacity differed according to the SOM content. For samples with a SOM content in the range of 1.2 to $1.8 \%$, the sorption constants (Qmax and $b)$ did not correlate $(p>0.05)$ with SOM. However, for those samples with SOM between 2.3 and $4.6 \%$, not only the P sorption capacity decreased significantly (Qmax; $p<0.01$ ) but also decreased the binding energy of phosphate sorption (b; $p<0.05$ ) to the solid soil phase, as described by the Equations 6 and 7.

$$
Q_{\max }=-41.272 \mathrm{SOM}+298.37 \quad \mathrm{R}^{2}=0.73(p<0.01)
$$




$$
b=-15.541 \mathrm{SOM}+115.20 \quad \mathrm{R}^{2}=0.65(p<0.01)
$$

\section{Discussion}

After two years since the OPP's start, overall SOM and soil P accumulation can be observed above the background soil values (Figures 2 and 3). The higher SOM and $\mathrm{P}$ accumulation values occurred mainly at lower elevation spots corresponding also to the surrounding area of feeders and wells. It is difficult to discriminate the effect on SOM and soil $\mathrm{P}$ accumulation caused by the elevation/slope and by the fixed location of feeding points because they are coincident in spatial terms. Eriksen and Kristensen [44] also found a high correlation between $\mathrm{N}, \mathrm{P}$ and $\mathrm{K}$ accumulation on soil and the distance to feeders. In addition to slope and the daily feed inputs, the pig's behaviour also strongly influenced the spatial heterogeneity of SOM and soil P. Watson et al. [8] refers that the preferred areas for excretion are out of the feeding zone and near the boundary of the paddocks. They observed in those select areas a P concentration on the top $0.05 \mathrm{~m}$, on average six times greater than in the least preferred areas, and a large proportion of the increase in soil $\mathrm{P}$ seems to be associated with organic $P$ forms. Salomon et al. [45] pointed out that 43 to $95 \%$ of nutrients were concentrated in preferred areas corresponding to $4-24 \%$ of the total pen area with an increase of $\mathrm{P}$ on the topsoil of the preferred areas more than fourfold. The high amount of P input to soil together with the rainfall that occurs in the OPP area mainly from October to May, as referred to in item 2.2, contributed to the downward movement of SOM and $\mathrm{P}$ forms not only in particulate forms (by erosion) but also in dissolved forms (in drainage or runoff waters). It was also observed that the content of dissolved $\mathrm{P}$ in drainage waters evaluated at $0.60 \mathrm{~m}$ depth was on average of $0.07 \mathrm{mg} \mathrm{L}^{-1}$ with maximum values of $0.34 \mathrm{mg} \mathrm{L}^{-1}$ (data not shown). The threshold value of groundwater quality is 0.1 to $0.2 \mathrm{mg} \mathrm{L}^{-1}[46,47]$. So, the drainage waters are a source of $P$ to groundwaters increasing the risk of eutrophication of waterbodies. Equation 5 showed that the most labile $\mathrm{P}$ forms easily available to crops or aquatic organisms (Olsen P) are on average $11 \%$ of the Pi forms. Olsen $\mathrm{P}$ showed high mobility in the paddocks, as shown by its broad soil changes (-82 to $884 \%$ in 2007). The heterogeneity in the spatial distribution of SOM and soil P is influenced by different factors, such as pigs' behaviour, soil erosion, fixed location of feeders and the $\mathrm{P}$ losses by runoff and drainage waters (Figures 2 and 3).

The decrease in soil P sorption with the SOM increase (Equation 6) was observed only in the set of soil samples with SOM $>2 \%$. This decrease in P sorption can be due to the competition for the same sorbing sites between the organic acids from the mineralization of SOM and the phosphate anions [16-18]. The SOM added to soil; namely, the pig excreta had a low $(\approx 11) \mathrm{C} / \mathrm{N}$ ratio [48] and consequently a high potential to release organic acids through a high mineralization rate. In addition to the negative correlation between SOM and Qmax, the negative correlation (Equation 7) between SOM and the binding energy of $\mathrm{P}$ to the solid soil phase ( $\mathrm{b}$ value evaluated by the Temkin isotherm) showed a high potential of this soil to maintain in solution labile $\mathrm{P}$ forms which are easily lost to drainage and runoff waters. Hunt et al. [35] also reported that soil inputs of biosolids seem to decrease the capacity of soil to sorb P and decrease the energy of phosphate bounding to the solid soil phase. Although we cannot find values of $\mathrm{P}$ losses in runoff waters from OPP areas in the published research works, Watson et al. [8] referred that after 15 months of outdoor pig production, the soil profile was saturated with $\mathrm{P}$ and represent a significant environmental risk. Also, Sharifi et al. [28] observed the movement down to soil profile of Olsen $\mathrm{P}$, organic and total $\mathrm{P}$ at an outdoor area of farrowing sows. In addition, the work of Horta and Torrent [39] regarding the acidic Portuguese soils indicated an Olsen P level of $20 \mathrm{mg} \mathrm{kg}^{-1}$ or $50 \mathrm{mg} \mathrm{kg}^{-1}$ as the threshold level to prevent a significant increase of losses of $P$ from soils to drainage or runoff waters. Other works with the soil of different properties indicated values of Olsen $P$ to prevent increasing losses to drainage waters of $36 \mathrm{mg} \mathrm{kg}^{-1}$ [49] and between $10-20 \mathrm{mg} \mathrm{kg}^{-1}$ [50, 51]. Since at the end of the experiment, SOM was higher than $2 \%$ in all the OPP area, and the Olsen P 
reached values of $49 \mathrm{mg} \mathrm{kg}^{-1}$ in some points, we can conclude that this area has a high potential to contribute to the eutrophication of waterbodies.

\section{Conclusions}

Two years after the beginning of the outdoor pig production, according to this work's hypothesis, there were an overall increase above the background value of the SOM and the soil P levels (Pi, Po and Olsen P). During this period, the area was not cultivated nor fertilized so, these inputs were due solely to the $\mathrm{P}$ and $\mathrm{OM}$ content of the feed and the pigs' excreta. The fixed eating points, the pig's behaviour, and the slope are the main factors affecting the spatial heterogeneity observed on this OPP's SOM and soil P content. The rainfall, concentrated in the winter season, and the bare soil favoured the soil erosion and the transport and accumulation of SOM and P to lower elevation spots or even outside of the OPP area. The increase of SOM to values above $2 \%$ caused a decrease in the soil P sorption capacity and the binding energy of phosphate to soil and consequently a high capacity of the soil to maintain in solution labile forms of $\mathrm{P}$ with high solubility and mobility. After two years from the beginning of the experiment, all the OPP areas had a SOM content higher than $2 \%$. To avoid significant SOM increases, the animal charge should be adequate for the soil properties. In addition to the effect of SOM on the decrease of $\mathrm{P}$ sorption, the high increase of labile soil $\mathrm{P}$ highlights a high risk of OPP areas for the eutrophication of waterbodies from non-point source pollution.

In order to prevent soil $\mathrm{P}$ accumulation and its losses (by erosion and by drainage or runoff waters), soil cultivation for pig grazing could be a cost-effective way to decrease soil P content and soil erosion.

Author Contributions: Conceptualization, CH.; methodology, C.H.; performed the experiments, C.H..; analyzed the data, C.H. and N.R.; writing, CH. All authors have read and agreed to the published version of the manuscript.

Funding: This research was funded by the CERNAS-IPCB [UIDB/00681/2020] supported by Foundation for Science and Technology (FCT).

Data Availability Statement: The data that support the findings of this study are available upon reasonable request.

Acknowledgements: The authors acknowledge the support of the School of Agriculture of the Polytechnic Institute of Castelo Branco, the CILCE for the English editing and Marta Batista for the support in the field experiments.

Conflicts of Interest: The authors reported no potential conflict of interest.

\section{References}

1. MacDowell, R.; Sharpley, A.; Withers, P. Indicator to Predict the movement of phosphorus from soil to subsurface flow. Environ. Sci. and Technol. 2002, 36, 1505-1509, https://doi.org/10.1021/es015675w.

2. Torrent, J.; Barberis, E.; Gil-Sotres, F. Agriculture as a source of phosphorus for eutrophication in southern Europe. Soil Use Manag. 2007, 23, 25-35, https://doi.org/10.1111/j.1475-2743.2007.00122.x.

3. Kleinman, P.J.A.; Sharpley, A.N.; Buda, A.R.; McDowell, R.W.; Allen, A.L. Soil controls of phosphorus in runoff: Management barriers and opportunities. Can. J. Soil Sci. 2011, 91, 329-338, http://doi.org/10.4141/CJSS09106.

4. Sauer, T.J.; Daniel, T.C.; Nichols, D.J.; West, C.P.; Moore, P.A.; Wheeler, G.I. Runoff water quality from poultry litter-treated pasture and forest sites. J. Environ. Qual. 2000, 29, 515-521, https://doi.org/10.2134/jeq2000.00472425002900020020x.

5. Sharpley, A.N.; Rekolainen. S. Phosphorus in agriculture and its environmental implications. p. 1-54 In: H. Tunney, O. T. Carton, P. C. Brookes, and A. E. Johnson, Eds. Phosphorus Losses from Soil to Water; CAB International, Cambridge, UK, 1997.

6. Sims, J.T.; Pierzynsky, G.M. Chemistry of phosphorus in soils. In M.A. Tabatabai and D.L. Sparks, Ed. Chemical Processes in Soils, SSSA Book Ser. 8. SSSA, Madison, WI, 2005; pp. 151-192.

7. Reid, K.; Schneider, K.D. Phosphorus accumulation in Canadian agricultural soils over thirty years. Can. J. Soil Sci. 2019, 99, 520-532, https://doi.org/10.1139/cjss-2019-0023.

8. Watson, C.; Atkins, T.; Bento, S.; Edwards, A.; Edwards, S. Appropriateness of nutrient budgets for environmental risk assessment: a case study of outdoor pig production. Eur. J. Agron. 2003, 20, 117-126, https://doi.org/10.1016/S11610301(03)00081-9. 
9. Shigaki, F.; Sharpley, A.; Prochnow, L. Rainfall intensity and phosphorus transport in surface runoff from soil trays. Sci Total Environ. 2007, 373, 334-343, https://doi.org/10.1016/j.scitotenv.2006.10.048.

10. Frossard, E.; Brossard, M.; Hedley, M.J.; Metherell, A. Reactions Controlling the Cycling of P in Soils. In Tiessen, H., Ed., Phosphorus in the Global Environment: Transfers, Cycles and Management; John Wiley \& Sons, New York, 1995; pp. 107137.

11. Torrent, J. Interactions between phosphate and iron oxide. In: Soils and Environment, K. Auerswald, H. Stanjek, and J. M. Bigham, Ed. Adv. GeoEcol. 30. Catena Verlag, Reiskirchen, Germany, 1997; pp. 321-344.

12. Borggaard, O.K.; Szilas, C.; Gimsing, A.L.; Rasmussen, L.H. Estimation of Phosphate Adsorption Capacity by Means of a Pedotransfer Function. Geoderma, 2004, 11, 55-61. https://doi.org/10.1016/S0016-7061(03)00183-6.

13. Gerke J.; Hermann, R. Adsorption of orthophosphate to humic-Fe-complexes and to amorphous Fe-oxide. Z. Pflanzenernahr. Bodenkd. 1992, 155, 233-236, https://doi.org/10.1002/jpln.19921550313.

14. Gérard, F. Clay Minerals, Iron/Aluminum Oxides, and Their Contribution to Phosphate Sorption in Soils - A Myth Revisited. Geoderma, 2016, 262, 213-226, https://doi.org/10.1016/j.geoderma.2015.08.036.

15. Guppy, C.N.; Menzies, N.W.; Moody, P.W.; Blamey, F.P.C. Competitive sorption reactions between phosphorus and organic matter in soil. A review. Aust. J. Soil Res. 2005, 43, 189-202, https://doi.org/10.1071/SR04049.

16. Sibanda, H.M.; Young, S.D. Competitive Adsorption of Humus Acids and Phosphate on Goethite, Gibbsite and Two Tropical Soils. Eur. J. Soil Sci. 1986, 37, 197-204, https://doi.org/10.1111/j.1365-2389.1986.tb00020.x.

17. Kaštelan-Macan, M.; Petrovic, M. Competitive Sorption of Phosphate and Marine Humic Substances on Suspended Particulate Matter. Water Sci. Technol. 1995, 32, 349-355, https://doi.org/10.2166/wst.1995.0702.

18. Antelo, J.; Arce, F.; Avena, M.; Fiol, S.; López, R.; Macías, F. Adsorption of a Soil Humic Acid at the Surface of Goethite and Its Competitive Interaction with Phosphate. Geoderma. 2007, 138, 12-19, https://doi.org/10.1016/j.geoderma.2006.10.011.

19. Gerke, J. Humic(OrganicMatter)-Al(Fe)-PhosphateComplexes:AnUnder- estimated Phosphate Form in Soils and Source of Plant-Available-Phosphate. Soil Sci. 2010, 175, 417-425, https://doi.org/10.1097/SS.0b013e3181f1b4dd.

20. Kwabiah, A.B.; Stoskopf, N.C.; Palm, C.A.; Voroney, R.P.; Rao, M.R.; Gacheru, E. Phosphorus Availability and Maize Response to Organic and Inorganic Fertilizer Inputs in a Short Term Study in Western Kenya. Agric. Ecosyst. and Environ. 2003, 95, 49-59, https://doi.org/10.1016/S0167-8809(02)00167-6.

21. Horta, C.; Roboredo, M.; Carneiro, J.P.; Duarte, A.C.; Torrent, J.; Sharpley, A. Organic Amendments as a Source of Phosphorus: Agronomic and Environmental Impact of Different Animal Manures Applied to an Acid Soil. Arch. Agron. Soil Sci. 2017, 63, 257-271, https://doi.org/10.1080/03650340.2017.1346372.

22. Bornett, H. L. I.; Guy, J.H.; Cain, P.J. Impact of animal welfare on cost and viability of pig production in the UK. J. Agric. Environ. Ethics. 2003, 16: 163-186, https://doi.org/10.1023/A:1022994131594.

23. Honeyman, M.S. Extensive bedded indoor and outdoor pig production systems in USA: Current trends and effects on animal care and product quality. Livest. Prod. Sci. 2005, 94, 15-24, https://doi.org/10.1016/j.livprodsci.2004.11.029.

24. Honeyman M.S.; Penner A. Outdoor vs indoor pig production in Iowa: an economic and production comparison. Swine Research Report; AS-627, ISU Extension Service, Ames, Iowa, 1995.

25. Park, H-S.; Min, B.; Oh, S-H. Research trends in outdoor pig production - A review. Asian-Australas J. Anim. Sci. 2017, 30, 1207-1214, https://doi.org/10.5713/ajas.17.0330.

26. Breeuwsma, A.; Reijjerink, J.G.A.; Schoumans. O.F. Impact of manure on accumulation and leaching of phosphate in areas of intensive livestock farming. In K. Steele, Ed. Animal Waste and the Land-Water Interface, CRC Press, Boca Raton, FL, 1995; pp. 239-249.

27. Koopmans, G.F.; W.J. Chardon, W.J.; Dolfing, J.; O.Oenema, O.; van der Meer, P.; van Riemsdijk. W.H. Wet chemical and phosphorus-31 nuclear magnetic resonance analysis of phosphorus speciation in a sandy soil receiving long-term fertilizer or animal manure applications. J. Environ. Qual. 2003, 31, 287-295, https://doi.org/10.2134/jeq2003.2870.

28. Sharifi M.; Messiga A.J.; Vakilian K.A.; Stopford, E.; Hutchinson, T. Spatial distribution of soil phosphorous fractions following 1-year farrowing sows in an outdoor hog-rearing farm in Eastern Canada. Environ. Monit. Assess. 2020, 192-322, https://doi.org/10.1007/s10661-020-08260-y.

29. Sharpley, A.N.; Smith, S.J.; Stewart, B.A.; Mathers, A.C. Forms of phosphorus in soil receiving cattle feedlot waste. J. Environ. Qual. 1984, 13, 211-215, https://doi.org/10.2134/jeq1984.00472425001300020007x.

30. Plaza, C.; Senesi, N.; García-Gil, J.C.; Brunetti, G.; D'Orazio, V.; Polo, A. Effects of pig slurry application on soils and soil humic acids. J. Agric. Food Chem. 2002, 50, 4867-4874, https://doi.org/10.1021/jf020195p.

31. Horta, M.C. Normal Climatológica 1986-2015; Posto Meteorológico Escola Superior Agrária. Instituto Politécnico de Castelo Branco, ESACB, Castelo Branco. 2016. http://meteo.esa.ipcb.pt.

32. IUSS Working Group WRB. World reference base for soil resources 2006; World Soil Resources Reports No. 103. FAO, Rome, 2006.

33. Fox, R.L.; Kamprath, E.J. Phosphate sorption isotherms for evaluating the phosphate requirements of soils. Soil Sci. Soc. Am. Proc. 1970, 34, 903-906, https://doi.org/10.2136/sssaj1970.03615995003400060025x.

34. Horta, M. C.; Torrent. J. Phosphorus desorption kinetics in relation to phosphorus forms and sorption properties of Portuguese acid soils. Soil Sci. 2007, 172, 631-638, http://doi.org/10.1097/ss.0b013e3180577270.

35. Hunt, J.F.; Ohno, T.; He, Z.; Honeycutt, C.W.; Dail, D.B. Inhibition of phosphorus sorption to goethite, gibbsite and kaolin by fresh and decomposed organic matter. Biol. Fertil. Soils. 2007, 44, 277-288, http://doi.org/10.1007/s00374-007-0202-1. 
36. Walkley, A.; Black, I.A. An Examination of the Degtjareff Method for Determining Soil Organic Matter, and a Proposed Modification of the Chromic Acid Titration Method. Soil Sci. 1934, 37, 29-38, https://doi.org/10.1097/00010694-19340100000003.

37. Deshpande, V.V.; Telang, M.S. Pipet Method of Sedimentation Analysis. Rapid Determination of Distribution of Particle Size. Anal. Chem. 1950, 22, 840-841, https://doi.org/10.1021/ac60042a033.

38. Olsen, S. R.; Cole, C.V.; Watanabe, F.S; Dean, L.A. Estimation of Available Phosphorus in Soils by Extraction with Sodium Bicarbonate; USDA United States Department of Agriculture. Circular Nr. 939, Washington D.C., 1954.

39. Horta, M. C.; Torrent, J. The Olsen P method as an agronomic and environmental test for predicting phosphate release from acid soils. Nutr. Cycling Agroecosyst. 2007, 77, 283-292, http://doi.org/10.1007/s10705-006-9066-2.

40. Olsen, S.R.; Sommers, L.E. Phosphorus. In Page, A.L. et al. Eds, Methods of Soil Analysis, Part 2, 2nd. Ed., Agron. Monogr. 9. ASA and ASSA, Madison, WI, 1982.

41. Murphy, J.; Riley, J. P. A modified single solution method for the determination of phosphate in natural waters. Anal. Chim. Acta. 1962, 27, 31-36, https://doi.org/10.1016/S0003-2670(00)88444-5.

42. Fernández, J.A.; Poulsen, H.D.; Boisen, S.; Rom, H.B. Nitrogen and phosphorus consumption, utilisation and losses in pig production: Denmark. Livest. Prod. Sci. 1999, 58, 225-242, https://doi.org/10.1016/S0301-6226(99)00011-1.

43. Daly, K.; Styles, D.; Lalor, S.; Wall, D.P. Phosphorus sorption, supply potential and availability in soils with contrasting parent material and soil chemical properties. Eur. J. of Soil Sci. 2015, 66, 792-801, https://doi.org/10.1111/ejss.12260.

44. Eriksen, J.; Kristensen, K. Nutrient excretion by outdoor pigs: a case study of distribution, utilization and potential for environmental impact. Soil Use Manag. 2001, 17, 21-29, https://doi.org/10.1111/j.1475-2743.2001.tb00004.x.

45. Salomon, E.; Akerhielm, H.; Lindahl, C.; Lindgren, K. Outdoor pig production fattening at two Swedish organic farms Spatial and temporal load of nutrients and potential environmental impact. Agric. Ecosyst. Environ. 2007, 121, 407-418, https://doi.org/10.1016/j.agee.2006.11.017.

46. Decree Law 236/98 de 1 Agosto. Diário da República I Série-A, №176.

47. Water Framework Directive 2000/60/CE, 23 October 2000.

48. Chen, H.; Wu, J.; Wang, H.; Zhou, Y.; Xiao, B.; Zhou, L.; Yu, G.; Yang, M.; Xiong, Y.; Wu, S. Dark co-fermentation of rice straw and pig manure for biohydrogen production: effects of different inoculum pretreatments and substrate mixing ratio. Environ. Technol. 2020, http://doi.org/10.1080/09593330.2020.1770340.

49. McDowell, R.; Sharpley, A.N. Approximating phosphorus release from soils to surface runoff and subsurface drainage. J Environ Qual. 2001, 30, 508-520, https://doi.org/10.2134/jeq2001.302508x.

50. Hesketh, N.; Brookes, P.C. Development of an indicator for risk of phosphorus leaching. J Environ Qual. 2000, 29, 105-110, https://doi.org/10.2134/jeq2000.00472425002900010013x.

51. McDowell, R.; Sharpley, A.N.; Brookes, P.; Poulton, P. Relationship between soil test phosphorus and phosphorus release to solution. Soil Sci. 2001, 166, 137-149, http://doi.org/10.1097/00010694-200102000-00007. 